\title{
A COASTAL DEVELOPMENT IDEA FOR GULF OF THAILAND TO IMPROVE GLOBAL TRADES
}

\author{
Chanin Chuen- $\operatorname{Im}^{1}$ and Jiin Jen Lee
}

\begin{abstract}
Marine transport is an important mode of transportation in global trades. Despite its slow speed, more than 80 percent of transporting goods around the world is by sea. At the present time, transportation between Pacific Ocean and the Middle East region are mainly from existing three routes: Malacca Route, Sunda Route, and Lombok Route. There are more than 500,000 ships of all sizes passing through these three routes every year. It would be advantageous from the economic point of view if one can shorten the travel distance by introducing a man-made canal herein called "Siam Canal" which connects the Andaman Sea and Gulf of Thailand. Hydrodynamic simulation is being conducted to evaluate the conditions before and after the introduction of "Siam Canal" to assess the possible modification of the marine environment. A more detailed feasibility study is underway in order to provide a more definitive assessment on the economic, social, political, and environmental impacts of the proposed Siam Canal.
\end{abstract}

Keywords: Coastal development, Improve Global trade, Man-Made Canal

\section{INTRODUCTION}

For a long time since ancient history, people have been using marine transport as a main transportation mode in global trades. The pioneers of marine transports in Greek, Roman, and China used sea routes to sell and buy goods for their respective kingdoms. Until now more than 80 percent of transporting goods around the world is still by sea even though the speed of sea transportation is much slower compared to air or ground transportation. There are many international sea routes for trading around the world as shown in Figure 1. Most of these travel routes are natural but some are man-made. Since there are many natural sea routes around the world already, why would people build man-made canal? The answer is very simple and straightforward: using man-made canals could make the shipping easier and more effective. Suez Canal connecting the Mediterranean Sea and the Red Sea, and the Panama Canal connecting Caribbean and the Pacific Ocean are the best examples of the man-made canals that show the necessity and the importance of what the alternative sea routes could do. At the present time, transportation between Pacific Ocean and the Middle East region are mainly from the existing three routes Malacca Route, Sandra Route, and Lombok Route as shown in Figure 2.

Every year, there are more than 500,000 ships of all sizes passing through these three routes: Malacca, Sunda, and Lombok Routes. It would be advantageous from the economic point of view if one can shorten the travel distance between Pacific Ocean and Indian Ocean. By introducing a manmade canal herein called "Siam Canal" located in Thailand (which connects the Andaman Sea and Gulf of Thailand) one can shorten the travel distance between Pacific Ocean and Middle East region significantly. Thus "Siam Canal" may become an important economic sea route in the Southeast Asia.

\section{THE PROPOSED "SIAM CANAL"}

At the present time, transportation between Pacific Ocean and the Middle East region are mainly from existing three routes as shown in Figure 2. The first route is Malacca Route that goes through Strait of Malacca, which is a long and narrow stretch of water between Malaysia and Indonesian Island. The Strait of Malacca is one of the most important marine shipping routes in the world. Malacca Route is the main shipping channel between the Indian Ocean and the Pacific Ocean, linking major Asian economies such as India, China, Japan, and South Korea. The second route is Sunda Route, which is located between the Indonesian Islands of Java and Sumatra. It connects the Java Sea to the Indian Ocean. The third route is Lombok Route, which also connects the Java Sea to the Indian Ocean. Lombok route locates between the islands of Bali and Lombok in Indonesia. Because Lombok Route is 250 meter in depth which is much deeper than Malacca and Sunda Routes, big vessels that need more than 25 meter of water depth will use Lombok Route. If the "Siam Canal" becomes a reality, it will be the fourth route. Figure 2 shows the new Siam Canal Route (denoted as fourth route) compared with the existing three routes.

\footnotetext{
${ }^{1}$ Sonny Astani Department of Civil and Environmental Engineering, University of Southern California, Los Angeles, Califirnia,90089-2531, USA.
} 


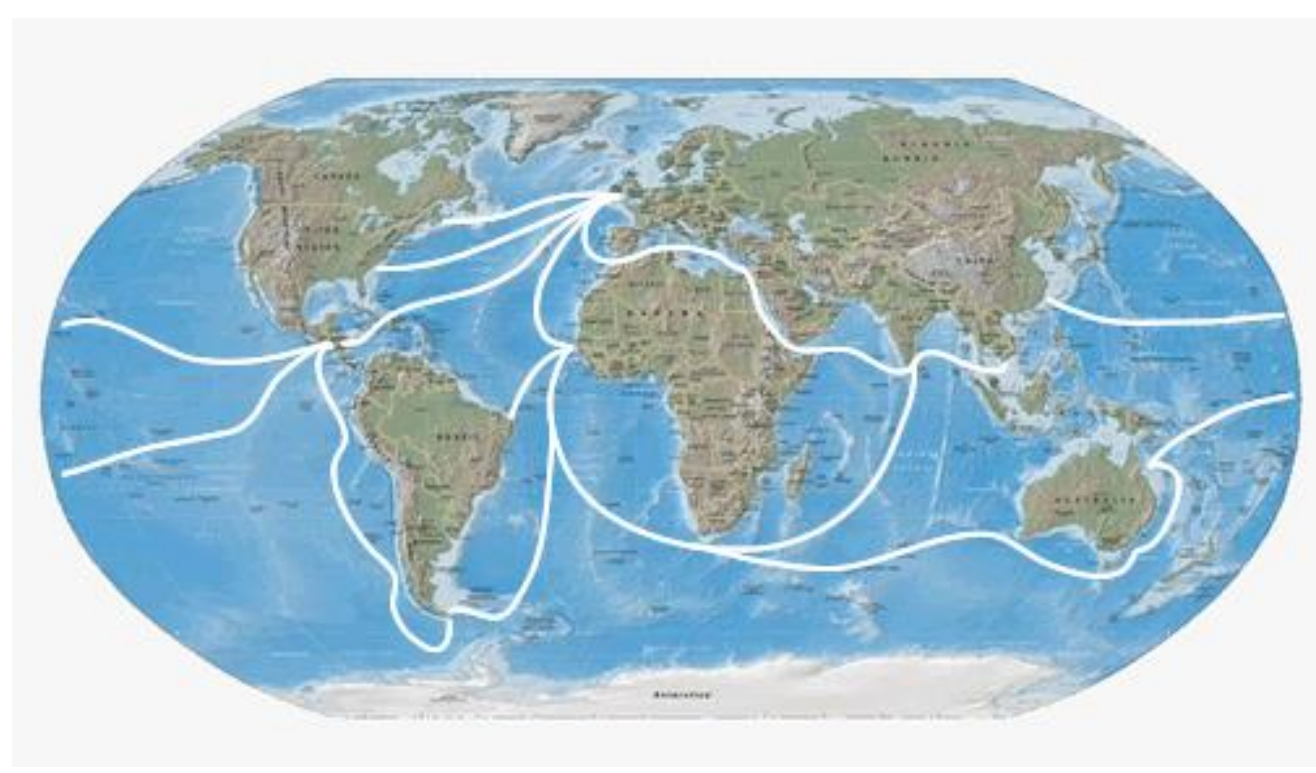

Figure 1. The sea routes around the world (Source: Giant Logistic LTD)

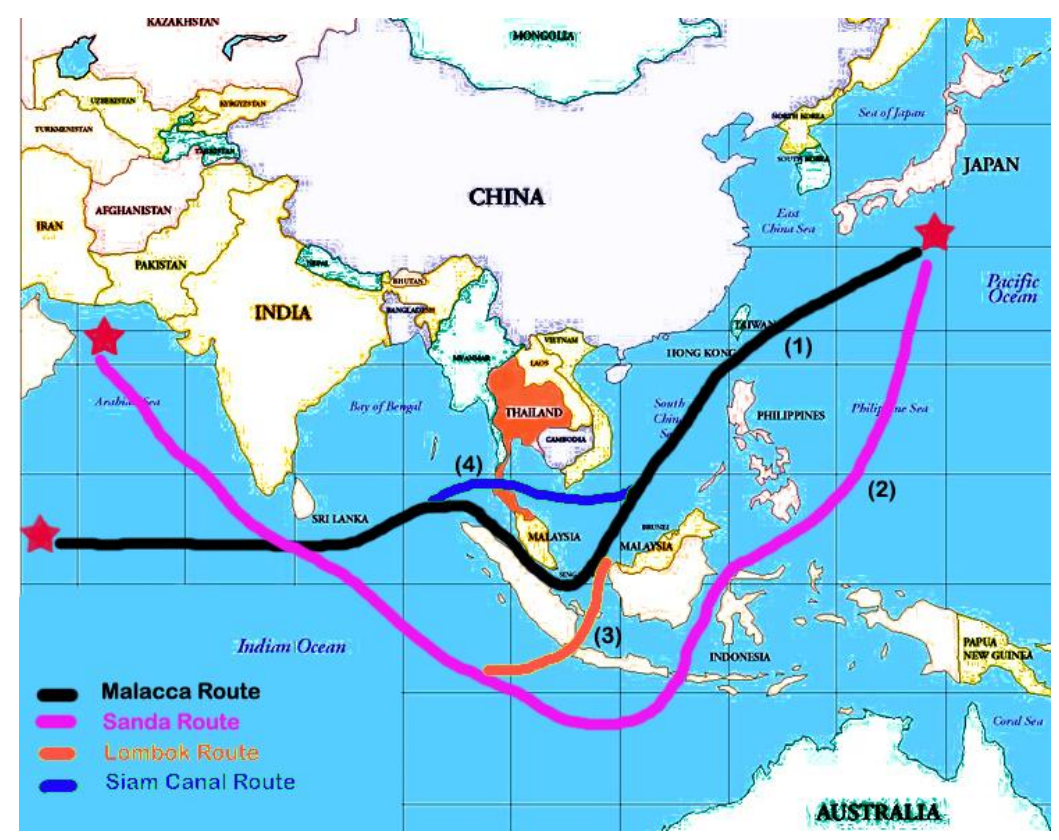

Figure 2. Location of the proposed Siam Canal compared with existing three routes

The idea of "Siam Canal" is similar to the Suez Canal connecting the Mediterranean Sea and the Red Sea, and the Panama Canal connecting Caribbean and the Pacific Ocean. We used Suez Canal and Panama Canal as case studies to begin our exploratory investigation. The location of proposed Siam Canal will be in the southern part of Thailand. Thailand is located in Southeast Asia and the geography of Thailand with its southward elongated orientation, blocks the path to Southeast Asia for marine traffic to and from the Middle East region.

The land that blocks the path is fairly narrow with the narrowest region with around $100 \mathrm{~km}$. The Route of "Siam Canal" will pass through five districts in Thailand, and they are: Krabi, Trang, Phatthalung, Nakhon Si Thammarat, and Songkhla. This Route has the narrow distance of $120 \mathrm{~km}$. Even though this is not the narrowest area in Thailand that connects the two oceans but $95 \%$ of the population in this area is among the poorest people in Thailand. The density of the population in this area is very low. $80 \%$ of the land along this Route is undeveloped area. Since the soil is sour, it is not good for agriculture use. Therefore, using this land for the construction of Siam Canal would be 
another advantageous point. Therefore, this is the preferred location to build the "Siam Canal". The location of the canal is indicated in Figure 3.

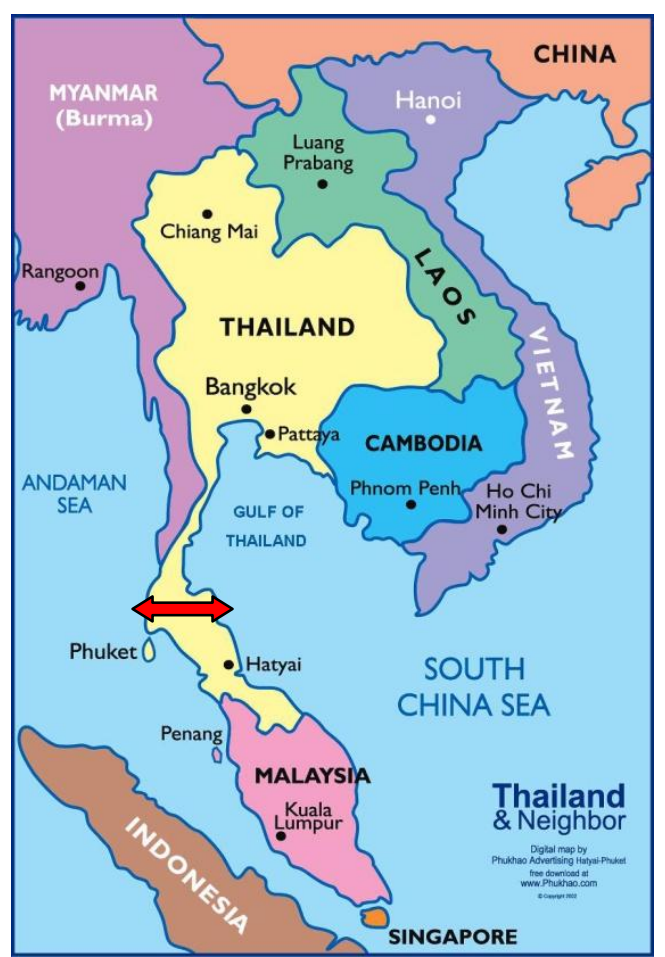

Figure 3. Location of the proposed Siam Canal

\section{The Potential Benefits from "Siam Canal" Project}

Building Siam Canal is a project requiring a big capital cost, and it would be the biggest engineering project in Thailand history. The main part of this paper is centered on assessing the economic feasibility of the project. The following is a list of potential benefits that could be expected from the "Siam Canal" project.

1. Save time of transportation: The distance and time comparisons of the present three routes with the Siam canal route are shown in Table 1.

\begin{tabular}{|c|c|}
\hline $\begin{array}{c}\text { Table 1. The distance and time saving using Siam } \\
\text { Canal compare to existing three routes. }\end{array}$ \\
\hline \multicolumn{2}{|c|}{ Distance saving compared to the following } \\
\hline Malacca Route & $1,200-1,400 \mathrm{~km}$. \\
\hline Lombok Route & $2,500-3,000 \mathrm{~km}$. \\
\hline Sunda Route & $3,000-3,500 \mathrm{~km}$. \\
\hline Time saving compared to the following \\
\hline Malacca Route & $2-3$ days \\
\hline Lombok Route & $4-5$ days \\
\hline Sunda Route & $5-7$ days \\
\hline
\end{tabular}

From Table 1, it seems that the travel time could be significantly reduced. Two or three days of saving could be expected when compared with the Malacca Route; four to five days of time saving could be expected when compared with Lombok Route. When compared with Sunda Route, a saving of five to seven days could be expected via the proposed "Siam Canal". 
2. Saving in terms of energy: Queen Elizabeth II uses $29 \mathrm{ft} / \mathrm{gallon}$ or 200 gallons per mile or 125 gallon per $\mathrm{km}$. Therefore saving a distance of $1,000 \mathrm{~km}$ means each ship can save more than 125,000 gallon of gasoline if traveling in Siam canal instate of Malacca Route. If using Siam Canal instate of Sunda route, the ship can save up to 400,000 gallon of gasoline.

3. Saving in terms of money: The major part of the cost in marine transportation is the cost of insurance which is approximately $0.5 \%$ of the cost of the total value per day. If the vessel have 1,000 TEU (TEU: Twenty-foot Equivalent Unit) and each container has a value of $\$ 50,000$. It means that the insurance cost each day is $\$ 0.25$ million. The big vessel can go up to 8,000 TEU which means it can save up to $\$ 2$ million per day or up to $\$ 14$ million per trip just on insurance cost alone.

4. The proposed "Siam Canal" would help Thailand economy and would create jobs for Thai people. When the Siam Canal is constructed, it would bring huge financial benefits for Thailand. Every country that has sea freight ships will be benefited. When the Siam Canal is built, both sides of the Canal will have global economic cities, attracting currency from every part of the world. The Siam Canal will change the situation of Thailand's economy enormously. Since the start of the Siam Canal construction, it will create 2-3 million jobs, and benefit many generations to come.

\section{Will there be enough ships passing the canal to make Siam Canal profitable?}

While ships can pass through the Malacca strait for free. The costs of passing through the Siam Canal must be a lot less than the cost that the ships have to pay for the operation each day compared with using the regular sea routes. Siam Canal will make the ships pass through easier compared to the old sea routes. In addition it would provide more security to all the ships that use the canal. Piracy in the Malacca Route has risen in recent years. The problems involving damages and losses caused by terrorist or pirates passing through those three routes occur frequently. There were around 25 attacks on vessels in 1994, 150 in 2000, and over 220 in 2008 (Royal Thai Navy). The reason of more raids of cargo ships is because ships have to pass straits in the three routes that have many capes and islands that are good hiding places for terrorists and pirates and it is hard to prevent or to eliminate. Ship officials would not take the risk to fight with these outlaws because a ship cargo values several billion baht and their ships need to pass through these routes very often. As a consequence, they choose to pay illegal escort or passing fees.

At the present time, there are around 520,000 ships passing through the south of Thailand every year (Royal Thai Navy), or around 1,300 - 1,400 ships every day. There are 600 ships docking at Singapore every day waiting to pass through the Malacca strait. The ships that will be the main customer for Siam canal are the big ships that need more than 20 meters water depth. These big ships normally have to go through Sunda Route and Lombok Route because the Malacca strait cannot support the ships that need more than 20 meters of water depth. Siam Canal will be able to service around 300-400 ships every day so there will be several hundred ships that will have to pass through the old route.

\section{CASE STUDY}

\section{Suez Canal}

The Suez Canal is a man-made canal in Egypt, opened in 1869 (Fitzgerald 1978). Suez Canal allows water transportation between Europe and Asia without circumnavigation of Africa, and avoids carrying goods overland between the Mediterranean and the Red Sea. The map and the location of Suez Canal are shown in Figure 4. The canal was 193 kilometer long and it took 10 years to build the canal. The construction started on April 25, 1859 and opened on November 17, 1869. The approximate cost of the project was 100 million dollars and now it brings Egypt more than 3,000 million dollars income for a year. As of today Suez Canal allows less than 100 ships to use the canal every day. This is because Suez Canal is a single lane canal that means the ships cannot go both directions at the same time (Higiro 1964). This is the main reason that the canal is not very efficient. A picture of Suez Canal is shown in Figure 5. 


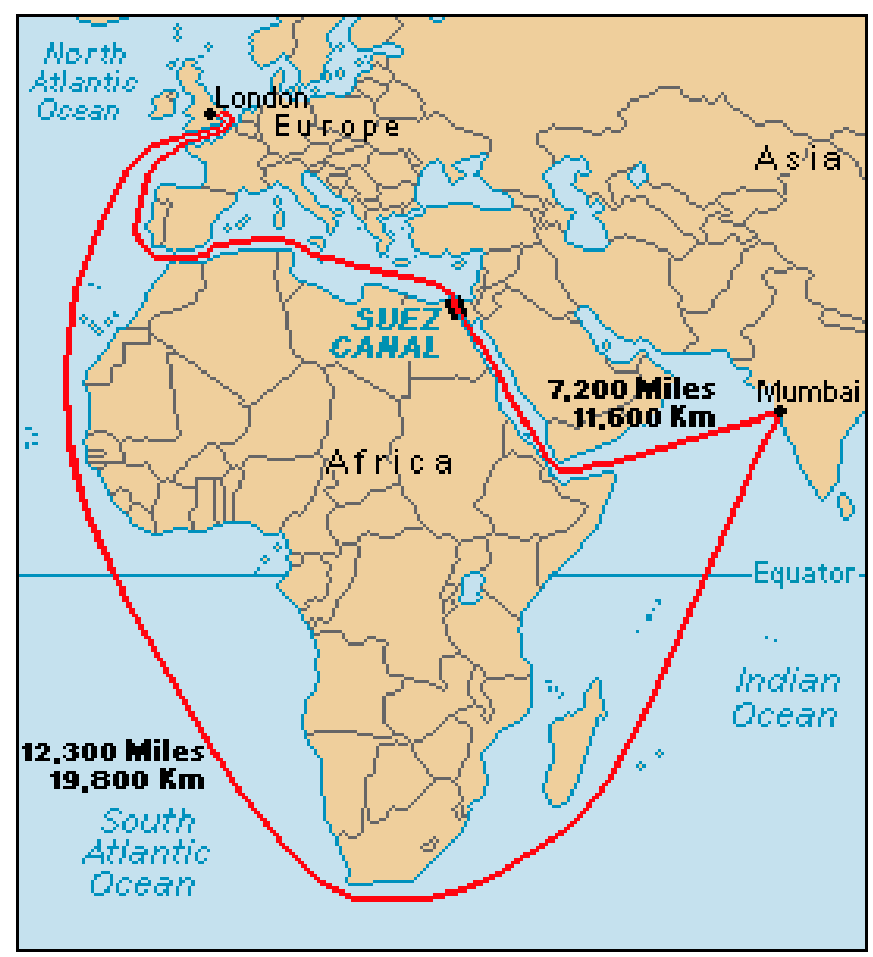

Figure 4. Location of Suez Canal (Source: www.howstuffwork.com)

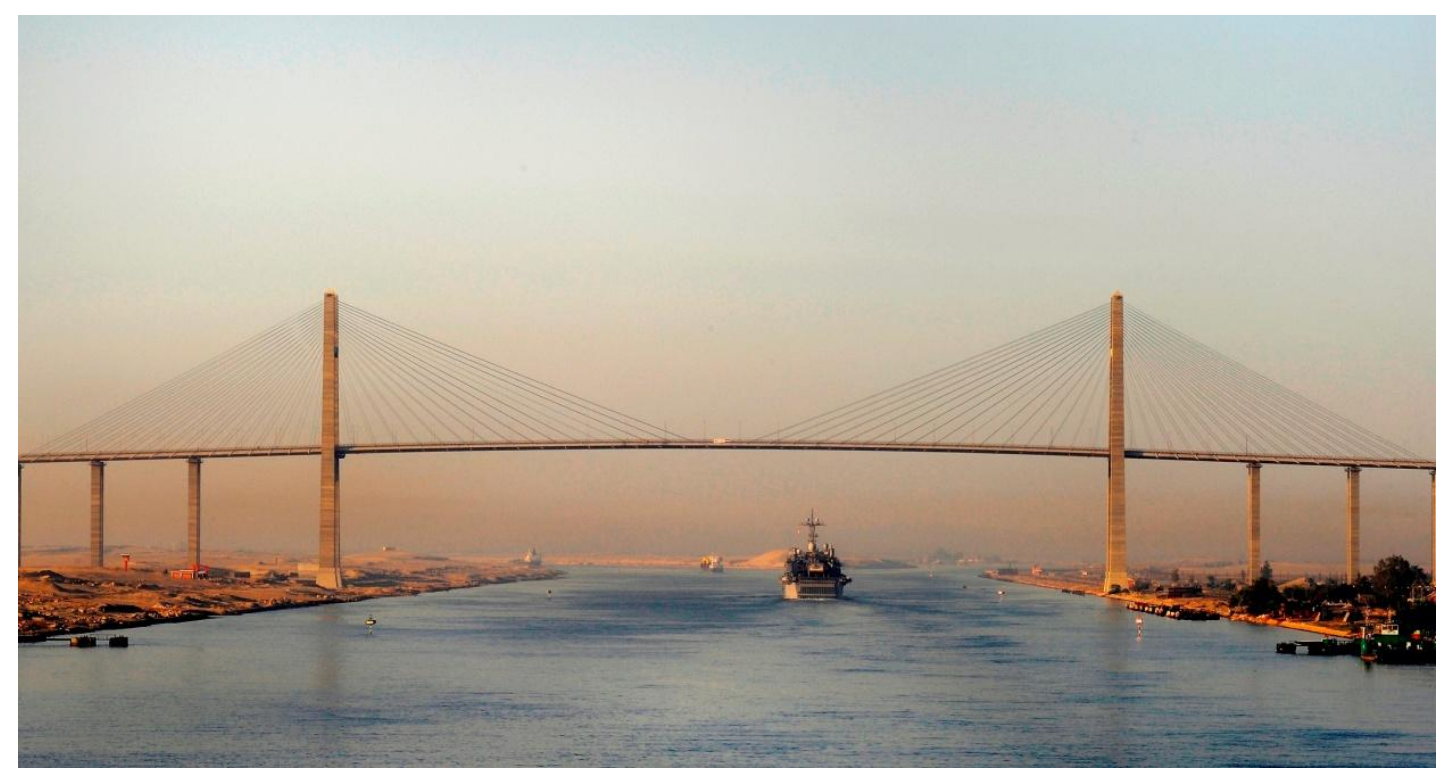

Figure 5. Picture of Suez Canal (Source: www.wikimedia.org)

\section{Panama Canal}

Panama Canal is located in Panama to join the Atlantic Ocean and the Pacific Ocean. The first attempt to construct the canal began in 1880 by French but was not successful until the United States continued with the second effort. It started functioning in 1914 (Bakenhus, R.E., H.S., et al. 1915). The Panama Canal is a $77 \mathrm{~km}$ or $48 \mathrm{mi}$ long and it took up to 10 hours to pass through the canal because the difference in water level between the two oceans is almost 20 meters. Water gate is used to regulate a proper water level so the ship can go pass the canal as shown in Figure 7. Even though it was not very convenient with this handicap, there were still more than 14,000 vessels used the canal in 2008 (Missal, A. 2008) because Panama Canal can save the travel distance up to 7,800 miles or 11,700 kilometers as shown in Figure 6. 


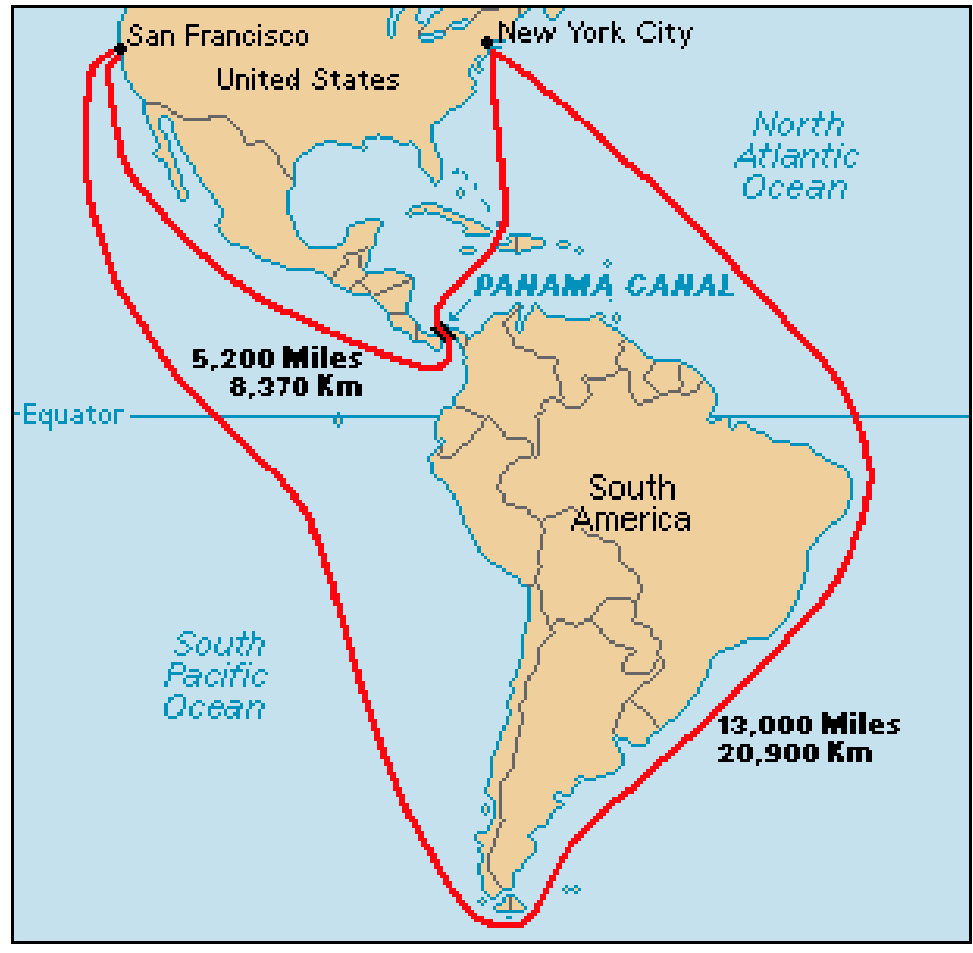

Figure 6. Location of Panama Canal (Source: www.howstuffwork.com)

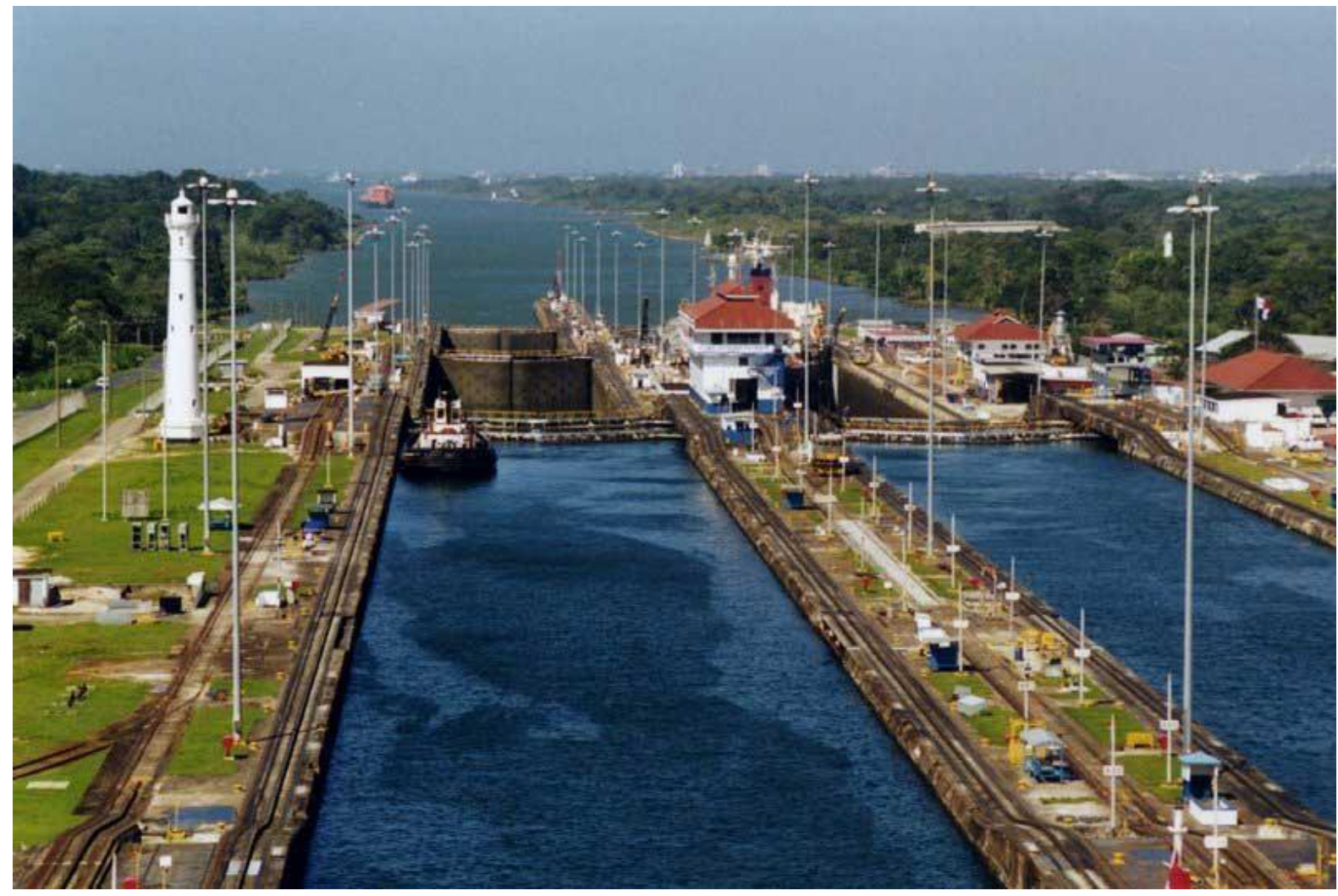

Figure 7. Water Gate used at Panama Canal (Source: Knightsbridge Investment Group) 


\section{INITIAL DESIGN OF THE PROPOSED SIAM CANAL}

Figure 8 shows the preliminary sketch of Siam Canal which will have two lanes. Learned from the experience of Suez Canal, one lane canal is not efficient because the ships have to go very slowly and require vast open spaces for the ships from one direction to wait until the ships from the other direction safely pass. It will be more costive if make one lane canal first and expand it into a two-lane canal later which is the problem that Suez Canal faces at the present time. The regular size of a big vessel is 65 to 90 meters in width; therefore each lane of the proposed Siam Canal should have a width of roughly 300 meters to ensure that ships can go through the canal conveniently. The fully loaded large vessels require a water depth of 30 to 35 meters. Thus it is suggested that Siam Canal should have 40 meters in depth to support the big sized ships, the main customers of Siam Canal. The perimeters will have to be paved 7-10 meters higher than the sea level to accommodate an industrial town with both high-tech industries and basic material industries. It is hard to tell that whether the amount of excavated earth will be enough for construction of facilities, such as harbors for loading and unloading cargos or for accommodating future expansion along the canal if possible. A detailed geographical and hydrographical survey must be conducted. If excavated earth is enough, it saves the cost of transportation of soil to build harbor facilities. Figure 9 shows an example of the facilities along the harbor.

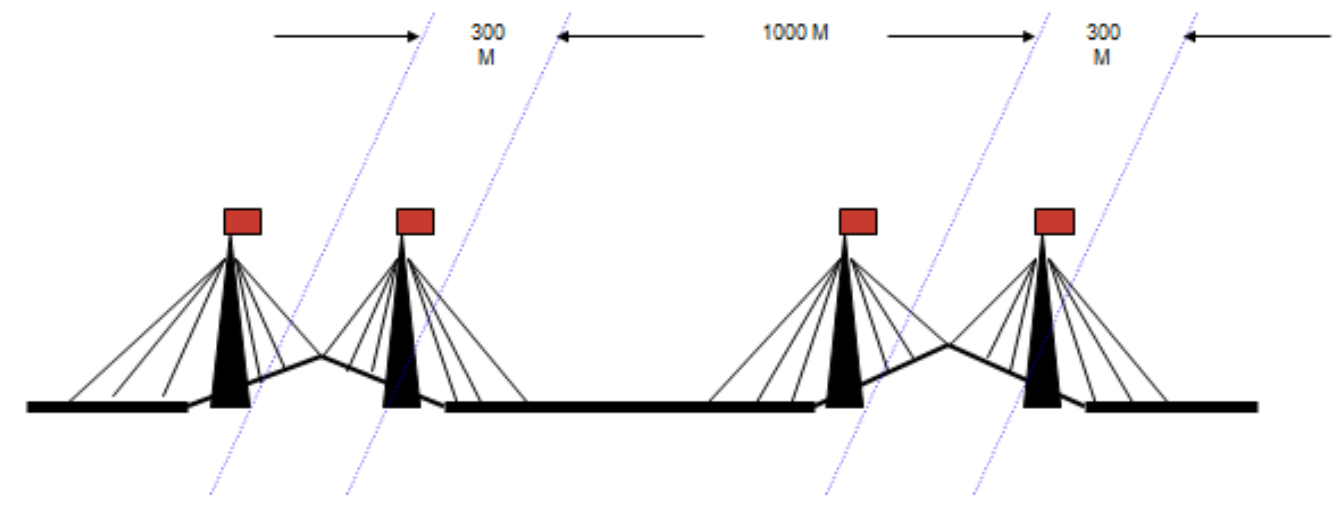

Figure 8. Sketch of the proposed Siam Canal

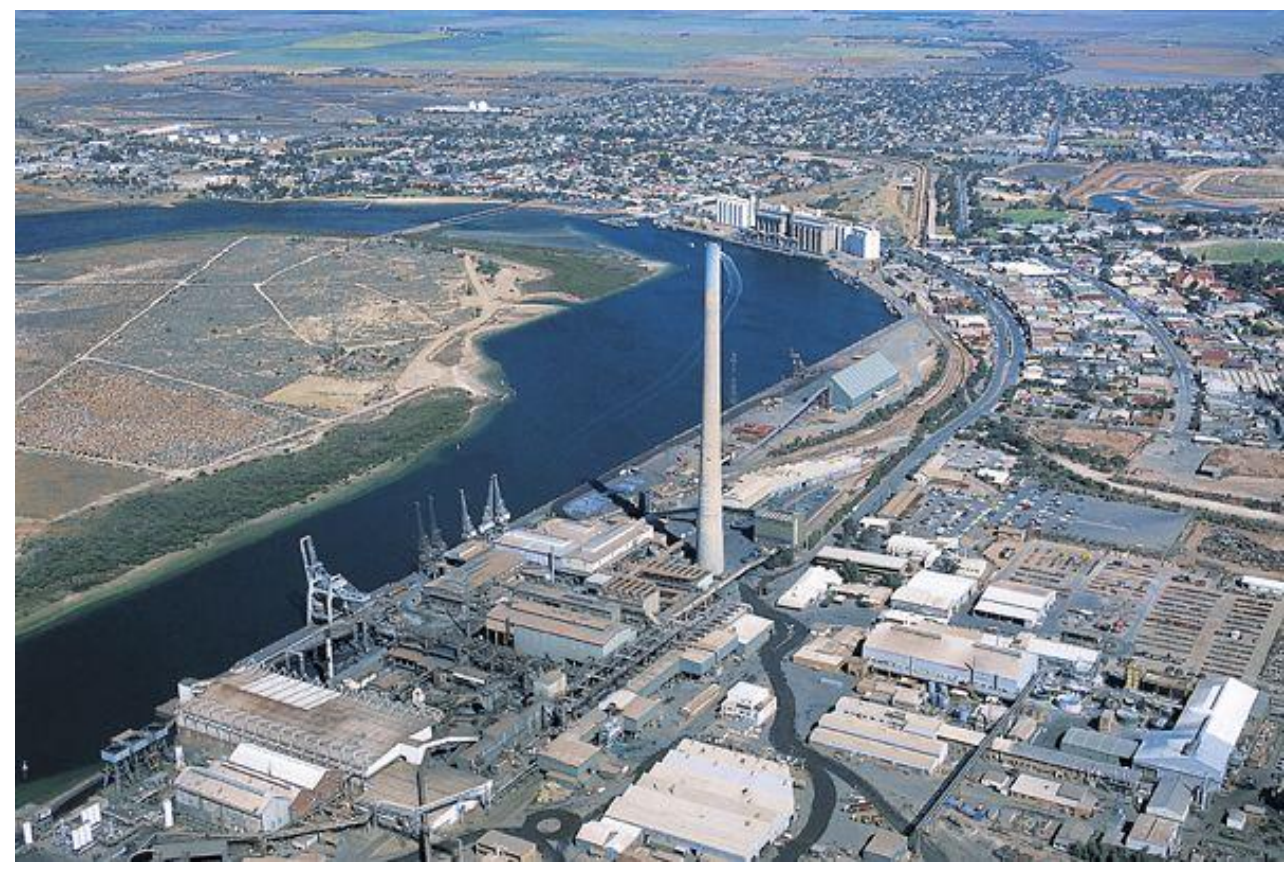

Figure 9. Example of facilities along the canal (Photo by Maggie Sayner) 


\section{Preliminary Cost Estimate for Construction of Siam Canal}

The construction cost for the Siam Canal project can be estimated by the main cost of the project, which is, the cost of the excavation and the construction cost of the bridges and tunnel crossing the Canal ( 3 bridges and 2 tunnels).The estimates for the excavation cost will be estimated based on the amount of earth to be excavated, which is around 4,000 million per cubic meter. If we estimate the handling cost for the earth at 150 Baht or \$5 US dollars per cubic meter, the excavation cost will be around 600,000 million Baht or $\$ 20,000$ million US dollars. The construction cost for the bridges is roughly 50,000 million Baht. So the total cost of the project is around 650,000 million Baht.

\section{Modeling of Wave and Tide Condition}

Possible environmental impacts due to the construction of the "Siam Canal" are evaluated. The wave and tide condition, before and after "Siam Canal" is being simulated by a finite element numerical model. The numerical simulation is based on the modeling of mild slope equation with the boundary conditions representing the various features encountered in the Gulf of Thailand. Figure 10 shows the large grid system used for the hydrodynamic simulation. Only the major grid blocks are indicated in Figure 10. The model grid contains 91,845 nodes and 22,500 elements for the numerical simulation. A detailed description of the model can be found in Lee and Xing (2010). Such simulation to predict the possible effects due to the construction of Siam Canal is important because any such effort must not affect tourism negatively as tourism is the key to the economy of Thailand.

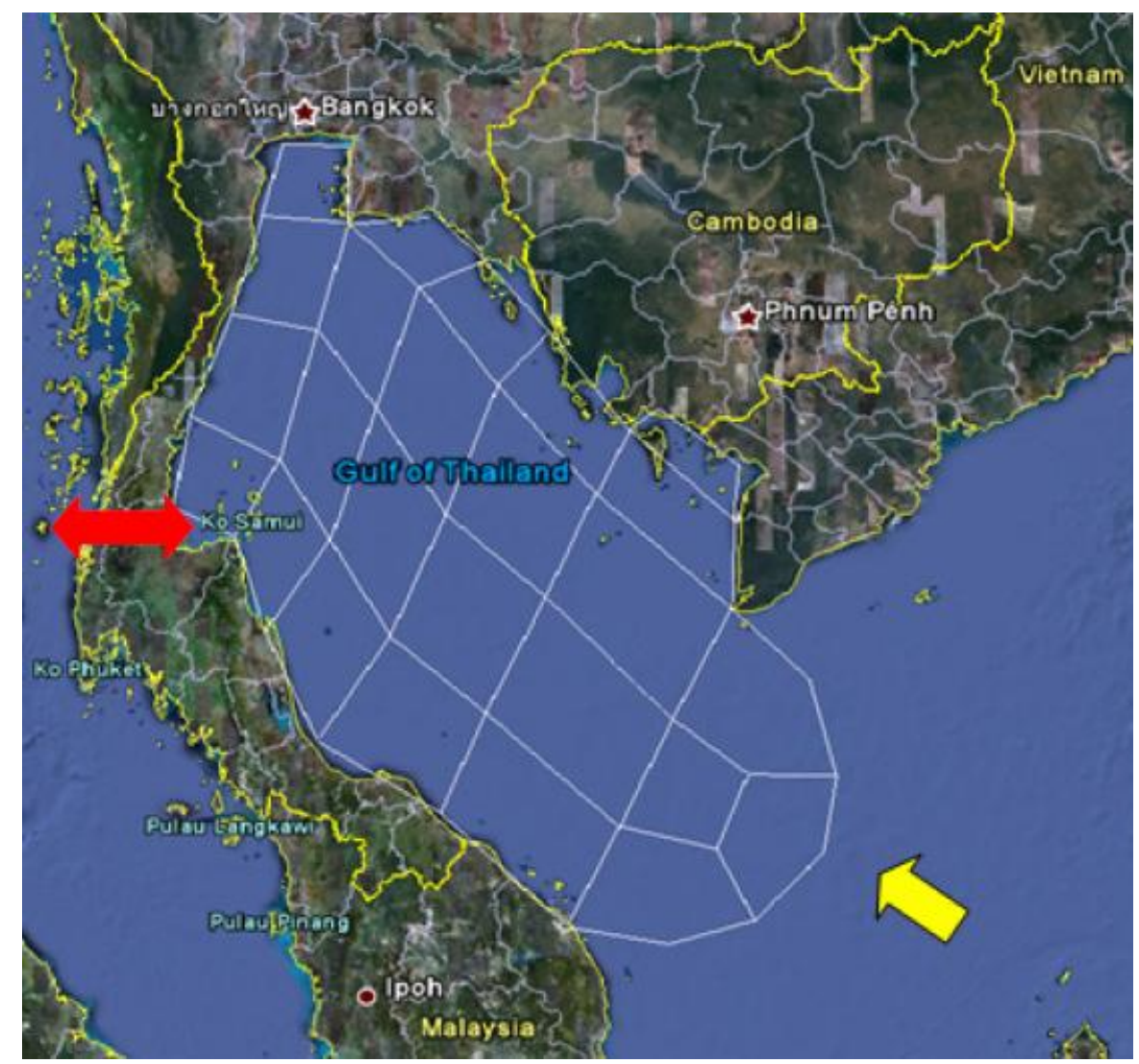

\section{Figure 10. Simulation Domain Used in the Numerical Study}

The result on the normalized tide level distribution obtained from the model is shown in Figure11. The result shows that tide levels surrounding the coastline of Gulf of Thailand are in general agreement with the tide records around the Gulf of Thailand. The effect due to the introduction of the proposed "Siam Canal" appears to be quite small in changing the tidal levels and the marine environment. With this small change of wave and tide condition, it appears that the proposed Siam Canal would not negatively affect the tourism. All beaches in Gulf of Thailand would not be negatively impacted by the construction of Siam Canal. 

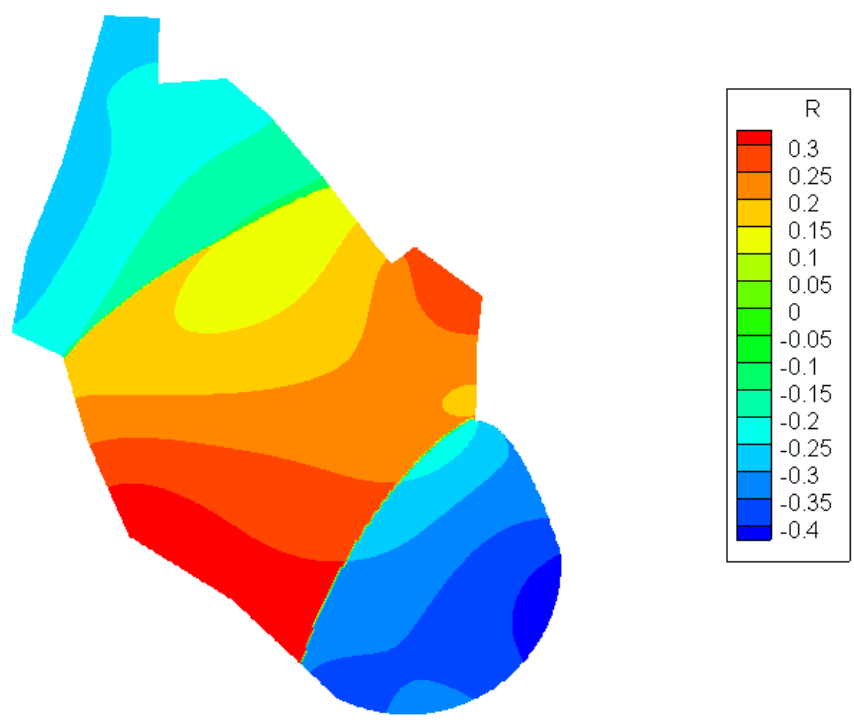

Figure 11. Distribution of Simulated Tide Level in Gulf of Thailand

\section{CONCLUDING REMARKS}

Based on this preliminary feasibility study it appears that the proposed "Siam Canal" is economically feasible and the canal would significantly improve the efficiency of global trades in South-East Asia. The construction of the canal in the underdeveloped area of Thailand would contribute to the economic boom never seen before. A more detailed feasibility study is currently underway so that a more definitive assessment on the economic, social, political, and environmental impacts can be made.

\section{REFERENCES}

Lee, J. J. and Xing X. Y. (2010). Computer modeling for harbor planning and design, Chapter 25, Handbook of Coastal and Ocean Engineering (edited by Y.C. Kim), World Scientific, pp 695- . 722.

Fitzgerald, P. H. (1978). The great canal at Suez, its political, engineering, and financial history : with an account of the struggles of its projector, Ferdinand de Lesseps. New York, AMS Press.

Higiro, F. S. G. (1964). The United Nations' contribution in the settlement of the Suez Canal crisis (1956) : an evaluation of the United Nations' mechanism as a peace keeping instrument, University of Southern California.: iii, 177 leaves.

Bakenhus, R. E., H. S. Knapp, et al. (1915). The Panama canal : comprising its history and construction, and its relation to the navy, international law and commerce. New York, J. Wiley \& Sons, Inc.

Missal, A. (2008). Seaway to the future : American social visions and the construction of the Panama Canal. Madison, Wis., University of Wisconsin Press.

Royal Thai Navy. http://navy.mi.th 